\title{
The timing of rights issues on the Johannesburg Stock Exchange
}

\author{
N. Bhana \\ Graduate School of Business, University of Durban-Westville, Private Bag X54001, Durban, 4000 Republic of South Africa
}

\begin{abstract}
Although a great deal of trading in rights transactions takes place on the various stock exchanges of the world, there is a dearth of empirical evidence which might determine an observable trading strategy related to such transactions. The traditional view is that subscription rights to additional issues of securities will reach their maximum price shortly after the start of trading and then decrease until the end of the subscription period. The results of this investigation into rights issues of companies listed on the JSE clearly rejects the 'sell the rights early' trading strategy. It is observed that there is a considerable number of rights which reach their peak price in the middle and in the final trading period. Empirical evidence presented in this paper reveals three factors that could be used to predict the market price of rights listed on the JSE. All three factors are highly correlated with the market price of rights. Therefore, an evaluation of an observable trend in these factors could be used to advantage by investors engaged in rights transactions.
\end{abstract}

\begin{abstract}
Ofskoon daar in baie handel gedryf word in regte-uitgifte op die verskeie effektebeurse van die wêreld, is daar nog 'n skaarste aan empiriese bewyse om 'n opmerkbare handelstrategie verwant aan sodanige transaksies te bepaal. Die tradisionele opvatting is dat subskripsie-uitgifte vir bykomende uitgifte van aandele hulle maksimum prys sal bereik kort na aanvang van handel en dan sal afneem tot die einde van die subskripsieperiode. Hierdie ondersoek dui daarop dat die regte-uitgifte van maatskappye wat op die Johannesburgse Effektebeurs genoteer is, bo alle twyfel die 'verkoop die regte vroeg' handelstrategie verwerp. Daar is bevind dat daar ' $n$ aansienlike aantal regte-uitgifte is wat hulle optimum prys teen die middel en aan die einde van die finale handelsperiode bereik. Empiriese bewyse gelewer in hierdie navorsingsprojek dui op drie faktore wat gebruik kan word om die markprys van die regte wat op die Johannesburgse Effektebeurs genoteer is, te voorspel. Al drie die faktore is ten nouste gekorreleer met die markprys van regte. 'n Evaluasie van 'n bespeurbare tendens in hierdie faktore kan daarom tot die voordeel van beleggers betrokke by regtetransaksies, gebruik word.
\end{abstract}

\section{Introduction}

The revival of activity on the Johannesburg Stock Exchange (JSE) during the past two years has resulted in several companies approaching shareholders for further funds by way of rights issues. The prime overdraft rate reached $25 \%$ in early 1985 and this provided an opportunity for listed companies to reduce their debt by substituting cheaper equity capital. Furthermore, the foreign exchange losses incurred by several large manufacturing companies in 1984 and 1985 resulted in these companies approaching the JSE for additional capital to increase their capital base. Shareholders of listed companies in South Africa have made substantial investments by taking up rights associated with their existing shareholding. It has been reported (McNulty, 1986: 39) that in 1985 listed companies in South Africa raised more than 2 billion rand by way of rights issues.

Although a great deal of trading of rights issues takes place on the JSE and various stock exchanges of the world, there seems to be widespread confusion among investors with regard to the mechanics of a rights issue. The purpose of this investigation is to dispel some of the myths and confusion surrounding rights issues. First, the process of selling securities through a rights issue and the market efficiency for such issues will be investigated. Second, an old adage established on the New York Stock Exchange (NYSE), namely, 'shareholders should sell rights early' will be tested for a sample of rights traded on the JSE. Based on this empirical evidence an appropriate strategy for trading in rights on the JSE will be presented.

\section{Selling securities through rights issues}

Instead of selling securities to the general public a company may offer them first to the existing shareholders on a privileged subscription basis. Frequently, the Articles of Association of a company require that additional issues of ordinary shares first be offered to existing shareholders because of their preemptive right. Under a pre-emptive right, the existing shareholders have the right to preserve their proportional shareholding in the company. When a company makes a rights issue to its existing shareholders, the share flotation is called a rights offering. Each shareholder is given an option to purchase a certain number of additional shares which enables him to preserve his proportional investment in the company. The share is said to be sold rights-on until the date of registration. After the registration date the shares are said to sell ex-rights, that is, the share is traded without the rights attached.

The principle of pre-emptive rights of existing shareholders has gained universal acceptance. In most countries the pre-emptive right is enshrined either in company legislation or the listing requirements of the various stock exchanges. In South Africa, the preemption right is not protected by the Companies Act of 1973, as amended. Section 144 of the Companies Act regards a rights issue to be a non-public offer, being a domestic concern between the company and its investors. However, the requirements for Articles of Association of the Johannesburg Stock Exchange (1976) provide for the pre-emptive right:

'Provision should be made in the Articles that unissued 
shares shall be offered to existing shareholders pro rata to their shareholding or that unissued shares and options to subscribe for unissued shares are only to be disposed of or dealt with as directed by a general meeting of shareholders'.

Fama, Fisher, Jensen \& Roll (1969) have provided evidence showing that there is a significant decline in share price associated with the announcement of a rights offering. The decline in share price can be explained in terms of the supply and demand mechanism. A rights issue increases the supply of shares in the market and unless there is a corresponding increase in demand, share prices must decline in value. Higgins (1977) suggests that the dilution in earnings per share associated with a rights issue leads to a corresponding decline in share price. Wakoff (1973) suggests that there are significant flotation costs associated with rights offerings and the decline in share price is the present value of these costs. Jones-Lee (1972) suggests that managements' and investors' expectations differ regarding the proceeds of a rights issue. If the investors' expectations are less optimistic than managements', a decline in share price is inevitable.

It is common practice for management to offer shares under a rights issue at a subscription price below the current market price of the share. Rights offerings have been viewed as share dividends or quasi-splits combined with share offerings (Levy \& Sarnat, 1971). Since share dividends or splits create no value, viewing a rights offering as a quasi-split means that there should be no abnormal returns after the announcement date. The findings reported by Hausman, West \& Largay (1971) provide support for this hypothesis. Scholes (1972) examined the price effects of rights offerings using the cumulative residuals approach. The conclusions reached were that the average residuals are positive prior to the date of issue and fall by $0,3 \%$ in the month of issue. Subsequent to the month of issue there did not appear, on average, to be any abnormal gains or losses. These results support the negative information and efficient markets hypothesis. White \& Lusztig (1980) have also shown that investors believe that there is negative information associated with a rights offering and that share prices adjust quickly and unbiasedly to new information.

Keane (1972) has demonstrated that if the issue price of a rights offering is below the prevailing market price of the shares, the issue price and the number of rights issued are irrelevant to the shareholder. Dipchand (1977) has shown that although rights are traditionally sold at a discount, a rights issue does not increase shareholders' wealth. Existing shareholders must, however, either exercise their rights or sell them in order to avoid suffering a decrease in the value of their investment. Therefore, from a shareholders' wealth point of view, a rights offering and a share split are similar - they are economically neutral. In the longterm shareholders are unlikely to derive any economic benefits from either rights offerings or share splits.

There have been no investigations into the behaviour of share prices around the announcement date of a rights issue in South Africa. However, as rights offerings can be viewed as quasi-splits combined with a share offering, the impact of a share split on the share price could provide insights into the likely influence of a rights offering on share prices. Cross \& Firer (1986) have investigated the impact of a share split on the share prices for a sample of companies listed on the JSE. It was reported that in line with prior research in overseas countries, their results suggest that no long-term economic benefits are likely to be obtained from a sharesplit. The results of Cross \& Firer (1986) indicate that while positive average residuals are observed in the period up to the announcement of a split, no abnormal returns can be expected after the split has become effective.

\section{Price movement of rights during the subscription period}

Trading in rights has increased substantially in recent years as large institutional investors have found this approach to be an ideal method for increasing their strategic holdings in target companies. Furthermore, rights issues are exempt from brokerage fees and other transaction costs are substantially lower than for normal share transactions. While a great deal of trading in rights takes place on the various stock exchanges of the world, there is a dearth of empirical studies to determine an observable trading startegy for rights issue transactions. 'Shareholders should sell rights early' is an old adage on the NYSE. The traditional view is that the subscription rights to additional issues of debt and equity capital will obtain their maximum price shortly after the start of trading, and then decrease in value until the end of the subscription period. This adage about selling subscription rights is a mere generalization. Nevertheless, this trading strategy continues to be used by investors dealing in rights on various stock exchanges including the JSE.

The general rule of selling rights early relies on a very simple logic - shareholders fail to act quickly once they have received subscription rights for an additional issue. This hesitation can be attributed to an immediate lack of funds and a desire to 'wait snd see' how the market will react to the rights issue. Regardless of the shareholders' motives, the effect is to establish a shortage of rights for several days after the trading begins, and the market price of the right rises relative to its theoretical value. As the end of the subscription draws near, many shareholders flood the market with subscription rights in a last effort to salvage what they can from their 'soon-tobe-worthless' rights and cause a decline in their prices. Once the assumption is made that most shareholders fail to act quickly upon receiving rights, this analysis appears to have a rational basis. An objection to this logic, however, is that no direct research into the shareholders' motives have been undertaken.

Although this behaviour may seem logical enough, empirical studies have not revealed any distinct pattern of rights over the subscription period. One reason is that arbitrage limits the deviation of the actual value from the 
theoretical value of the right. If the market price of a right is significantly higher than its theoretical value, shareholders will sell their rights and purchase shares in the market. Such action will exert downward pressure on the market price of the right. If the market price of a right is significantly lower than its theoretical value, shareholders will buy the rights, exercise their options to buy shares, and then sell the shares in the market. Such action will exert upward pressure on the market price of a right. These arbitrage transactions will continue as long as they are profitable to investors. Another reason to doubt the 'sell the rights early' adage is that in recent years the markets have been dominated by institutional investors. These investors possess vast resources and are managed by professionals and therefore are unlikely to be constrained by lack of funds or show a tendency towards procrastination.

Two major studies on the distribution of price movements associated with rights issues during the subscription period have been cited in the literature. Leffler (1957) analysed all 75 rights offerings traded on the NYSE during the 18 months ending 30 June 1957. The subscription period was divided into three equal parts: the first, middle and final periods. It was observed that there was an equal chance of a high price occurring in any three trading periods. Nineteen cases were considered inconclusive because they had identical highs in two or more of the three periods. Leffler (1957) also observed that 20 of the 75 issues reached their highest levels on the first trading day and that 22 issues peaked on the last day. Leffler (1957) concludes that his analysis does not support the 'sell rights early' hypothesis. On the contrary, a case might be established for selling rights on either the first or last day of trading.

Soldofsky \& Johnson (1967) have traced the price movements of 25 companies whose rights were traded on the NYSE during the 12 months ending 31 December 1966. The subscription period was again divided into three equal periods: the first, middle and final periods. In 14 cases, the subscription rights sold at their highest level in the first third interval of the subscription period. There were seven cases in which the rights reached their peaks in the final period. None of the rights reached their peak level in the middle period. In addition, four cases were considered inconclusive as they reached identical highs in two or more time periods. Soldofsky \& Johnson (1967: 103) conclude that their results suggest that a slight advantage might be gained by selling rights in the initial period. They also suggest that the following strategy can be stated with greater confidence: 'don't sell rights in the middle of the subscription period'. It was found that those rights which reached peaks in the middle period also reached identical peaks in the first or last periods.

\section{A strategy for trading rights on the JSE}

The empirical evidence does not support the traditional view regarding the optimal trading strategy for rights on the NYSE. The purpose of this investigation is to test the validity of the 'sell rights early' adage for companies listed on the JSE. A sample of 50 companies whose rights were traded on the JSE during the 36-month period 1 July 1984 - 30 June 1987 was chosen for analysis (Appendix A). The nature of the market was somewhat bearish in the 1984-85 period, whereas the 1986-87 period reflects a distinctly bullish period on the JSE. To check the accuracy of the terms of the rights issues, the offer documents related to the specific issues were consulted. The rights of companies listed on the JSE represent a negotiable instrument, and are freely traded on the stock exchange, i.e. nil-paid letters (NPLs). The subscription period was divided into three equal periods: the first, middle and final periods. The prices recorded were the daily closing prices of NPLs provided by the JSE computer and quoted by the various newspapers.

The trading period for the NPLs varied somewhat during the period under investigation. As a group the average length of time for which the rights (NPLs) were traded was about 18 days. During the early part of the investigation (1 July 1984 - 31 December 1985) the average time for trading in NPLs was about 20 days. The corresponding trading period for the later part of the investigation (1 January 1986 - 30 June 1987) was about 16 days. This difference might partially be explained by the difference in the general conditions on the JSE over the two time periods. The nature of the market during the first period (1984-85) was characterized by bearish investor sentiments, whereas in the second period (1986-87) the market was bullish. It is suggested that a longer period of time may have been considered necessary to distribute the rights to possibly hesitant or reluctant investors during the bearish period. For each of the 50 companies in the sample, the daily price movements of the NPLs during the subscription period was monitored. The results are shown in Table 1.

These results indicate that there is a wide divergence in the periods in which the peak values in rights issues occur. In 17 out of the 50 issues investigated, the prices peaked in the final trading period. There were 16 cases in which the rights reached their highest price in the first third of the trading period. Furthermore, there were eight cases where the rights reached their maximum price in the second or middle trading period. These results clearly reject the 'sell rights early' trading strategy as there was an almost equal chance of a high price occurring in the first or final trading period. In fact, more highs were found in the final period in comparison

Table 1 The distribution of peak prices of rights issued by a sample of 50 companies on the JSE

\begin{tabular}{lcc}
\hline $\begin{array}{l}\text { Period in which the highest } \\
\text { price is reached }\end{array}$ & $\begin{array}{c}\text { Number of } \\
\text { companies }\end{array}$ & Percentage \\
\hline First & 16 & 32,0 \\
Middle & 8 & 16,0 \\
Final & 17 & 34,0 \\
Inconclusive & 9 & 18,0 \\
Total & 50 & 100,0 \\
\hline
\end{tabular}


with the first period (17 versus 16). Of particular interest is the observation that seven out of the 50 issues reached their highest levels on the first day of trading and nine issues peaked on the last trading day. This evidence further refutes the contention that rights issues are expected to reach a peak in the early days of trading.

Nine cases were considered inconclusive as they reached identical highs in two or more periods. Of these nine, two reached identical peaks in the first and middle period, two in the first and last period, a further four issues peaked in the middle and final period and the remaining one peaked in all three periods. Thus, of those considered inconclusive, a greater frequency of peaks occurred in the last period than in the first period. The results of this investigation lend support to the findings of the two previous studies on the NYSE relating to price movements of rights issues. These results suggest that the 'sell rights early' strategy is of doubtful validity because this study, as well as those on the NYSE have found that a considerable number of rights reach their peak prices in the middle and in the final trading period.

In demonstrating the mechanics of a rights issue, the underlying assumption is that the price of the NPLs is directly related to the differential between the subscription price and the market price (rights-on) of the security. Factors such as the general conditions of the stock market and other institutional and environmental factors are not supposed to influence the fluctuation in price of NPLs. This is hardly a realistic assumption. In reality, any factor that influences the demand and supply for the underlying share can be expected to have a significant impact on the ex-rights share price and this in turn can be expected to have an impact on NPL prices. The preceding analysis of the price movements of NPLs is deficient in that the underlying factors that may influence NPL prices during the subscription period have been precluded.

The market model developed by Sharpe (1970) demonstrates that all securities are affected to a greater or lesser extent by a common 'underlying factor' which represents developments in the 'overall market'. The market model also suggests that all securities including NPLs are influenced by the prevailing market sentiment. Furthermore, developments specific to a particular company may cause its securities either to move against the 'overall market' trends or to emphasize them. Company-specific factors that are most likely to influence the price of NPLs are the underlying share price and developments in the industry in which the company operates. Therefore, three factors, namely, market sentiment (JSE Overall Actuaries Index), underlying share price of the NPL and industry influence (industry index) have been chosen to determine what influence, if any, these factors have on the market price of NPLs.

For each of the 50 companies in the sample whose rights were traded on the JSE, the price movements of the NPLs and (i) associated change in the JSE Overall Actuaries Index, (ii) associated change in industry index, (iii) change in the underlying share price, were
Table 2 Simple regression to predict the price movements of NPLs for a sample of $\mathbf{5 0}$ companies on the JSE

\begin{tabular}{lcccc}
\hline & \multicolumn{4}{c}{ Standard } \\
Variable & Coefficient & error & $t$ Value & $\boldsymbol{r}$ Squared \\
\hline Intercept & 0,018 & 0,0019 & 9,4737 & \\
2. (Underlying share price) & 0,928 & 0,1351 & 6,8690 & \\
& & & & 0,9150 \\
Intercept & 0,031 & 0,0041 & 7,5610 & \\
3. (Industry index) & 0,840 & 0,1405 & 5,9786 & \\
& & & & 0,8672 \\
Intercept & 0,043 & 0,0062 & 6,9355 & \\
4. (Overall market index) & 0,793 & 0,1524 & 5,2034 & \\
& & & & 0,8024 \\
\hline
\end{tabular}

monitored. A simple regression analysis to predict the price movements of the NPLs (dependent variable) was undertaken using each of these three factors as independent variables. The results of the regression analysis are shown in Table 2 .

The results in Table 2 suggest that all three independent variables (underlying share price, change in industry prices and change in the overall market movement) could be chosen to predict the market price of rights (NPLs) listed on the JSE during the study period. The movement in underlying share price would be chosen as a basis for predicting the market price of rights, because it explains a higher percentage of past variations in the market price of NPLs $\left(r^{2}\right.$ of 0,9150 versus 0,8672 and 0,8024 for changes in industry prices and changes in overall market movement respectively). The $t$ values are significant for all three independent variables $(t>2)$. The highest $t$ value for the underlying share price (independent variable) reinforces its choice as the most useful predictor of price movements in NPLs.

As all three independent variables investigated have

Table 3 Multiple regression to predict the price movements of NPLs for a sample of 50 companies on the JSE

\begin{tabular}{|c|c|c|c|c|}
\hline \multirow[b]{2}{*}{ Variable } & \multicolumn{3}{|c|}{ Standard } & \multirow[b]{2}{*}{$r$ Squared } \\
\hline & Coefficient & error & $t$ Value & \\
\hline Intercept & 0,029 & 0,0136 & 2,1323 & \\
\hline 2. (Underlying share price) & 0,813 & 0,4321 & 1,8815 & \\
\hline 3. (Industry index) & 0,539 & 0,4004 & 1,3462 & \\
\hline \multirow[t]{2}{*}{ 4. (Overall market index) } & 0,466 & 0,4378 & 1,0644 & \\
\hline & & & & 0,937 \\
\hline \multicolumn{5}{|c|}{ Correlation coefficients } \\
\hline Variable & 2 & 3 & 4 & \\
\hline 2 & 1,000 & 0,909 & 0,866 & \\
\hline 3 & 0,909 & 1,000 & 0,827 & \\
\hline 4 & 0,866 & 0,827 & 1,000 & \\
\hline
\end{tabular}


high coefficients of determination $\left(r^{2}\right)$, it was decided to analyse the movement in the price of rights in relation to the three independent variables simultaneously. The use of all three variables together may well improve the accuracy as well as the confidence in predicting the market price of rights. Therefore, multiple regression analysis was undertaken to determine the joint influence of the three independent variables on the fluctuation in NPL prices. The results are presented in Table 3.

The coefficient of determination $\left(r^{2}=0,937\right)$ in Table 3 is higher than the $r^{2}$ for the individual variables tested for simple regression (Table 2). Therefore, as long as past relationships of the underlying share prices, changes in industry prices and changes in overall market movements are maintained, multiple regression can be expected to be more useful than simple regression in predicting the price of NPLs. However, there is a significant deterioration in the $t$ values of the individual coefficients presented in Table 3. The lower $t$ values indicate the presence of multicollinearity. Therefore, we have less confidence about the joint influence of individual variables in predicting the market price of rights. The presence of a high $r^{2}(0,937)$ together with coefficients bearing low $t$ values (less than 2) confirms the presence of multicollinearity (Johnston, 1972). The increased values of the standard errors suggest that a high correlation exists between the independent variables (Kaplan, 1982).

When multicollinearity exists, the independent variables are highly correlated with each other. Therefore, the regression coefficients may be unreliable for predicting the movement of the dependent variable. In this instance it is not possible to use multiple regression to disentangle the individual contributions of the underlying share prices, the movement in industry prices and overall market movements in predicting the market value of rights. The results in Table 3 show a high degree of correlation between movement in the market price of rights and the three independent variables. Therefore, investors trading in rights would do well to monitor these variables rather than rely on unsubstantiated market folklore such as 'sell your rights early'.

\section{Conclusion}

The results of this investigation into the distribution of the price of rights traded on the JSE confirms the findings of previous studies on the NYSE. These results suggest that the 'sell the rights early' trading strategy is of doubtful validity because a considerable number of rights were observed to reach their peak price in the middle and final trading period. Furthermore, a significant number of rights reached their highest trading levels on the last trading day. The presence in the market of a large number of investors exploiting arbitrage opportunities will prevent any major deviation of the actual price from the theoretical value of a right. In addition, the securities markets are dominated by institutional investors who are unlikely to be constrained by a lack of funds or show a tendency towards procrastination. This refutes the basic logic of those supporting the unsubstantiated rule of thumb which suggests that rights reach their peak value in the early trading period.

A major deficiency of the traditional strategy on the timing of rights transactions is that the various factors that may influence NPL prices during the subscription period are ignored. This investigation has identified three factors that could be used to predict the market price of rights listed on the JSE. The changes in the underlying share price are the most important predictor of the movement in the price of rights of listed companies. Furthermore, perceptions of the industry in which the company operates and the general trend in the market during the subscription period also exert considerable influence on the price of rights. All three factors investigated are highly correlated with the market price of rights. Therefore, an evaluation of a discernable trend in these factors could be used to the advantage of investors engaged in rights transactions.

A limitation of this investigation is that only three factors likely to influence the price of rights have been explored. Therefore, it is suggested that follow-up studies on price fluctuations of rights which investigates several other institutional and environmental factors not included in this investigation may well assist in compiling an exhaustive list of variables and determining their joint influence in predicting the price of rights. For investors seeking a trading strategy, a useful guideline is to critically evaluate significant changes in the underlying share price, market perceptions of the industry involved and the overall market sentiment during the subscription period. The results of such an analysis may have a greater bearing on the price of rights rather than a rigid adherence to market folklore such as 'sell the rights early'.

\section{References}

Cross, T.A. \& Firer, C. 1986. Who benefits from share splits? S. Afr. J. Bus. Mgmt., vol. 17, 87-92.

Dipchand, C.R. 1977. The Canadian Experience with Inherent Stock Splits of Rights Issues. Finan. Manage., vol. 6, 34-41.

Fama, E.F., Fisher, L., Jensen, M.C. \& Roll, R. 1969. The adjustment of Stock Prices to New Information. Econ. Rev., vol. 10, 1-21.

Hausman, W.H., West, R.R. \& Largay, J.A. 1971. Stock Splits, Price Changes and Trading Profits: A Synthesis. J. Bus. vol.44,69-77.

Higgins, R. 1977. Financial Management: Theory and Applications. Palo Alto: Science Research Associates, Inc. Johnston, J. 1972. Econometric Methods. 2nd Edition. New York: McGraw-Hill.

Jones-Lee, M. 1972. Underwriting of Rights Issues: A Theoretical Justification. J. Bus. Fin., vol. 3. 20-25.

Kaplan, R. 1982. Advanced Management Accounting. Englewood Cliffs, New Jersey: Prentice-Hall.

Keane, S.M. 1972. The Significance of the Issue Price in Rights Issues. J. Bus. Fin., vol. 4, 40-45.

Leffler, G.L. 1957. Stock Rights. Barron's, 16 September, 15. 
Levy, H. \& Sarnat, M. 1971. Risk, Dividend Policy, and the Optimal Pricing of a Rights Offering. J. Money, Credit \& Banking, vol. 3, 840-849.

McNulty, A. 1986. Corporate Profits-Real hope or false down? Fin. Mail, vol. 102, 28 November, 38-39.

Scholes, M.S. 1972. The Market for Securities: Substitution versus Price Pressure and the Effects of Information on Share Price. J. Bus., vol. 45, 179-211.

Sharpe, W.F. 1970. Portfolio Theory and Capital Markets. New York: McGraw-Hill.

Soldofsky, R.M. \& Johnson, C.R. 1967. Rights Timing. Fin. Analysts J., vol. 23, 101-104.

The Johannesburg Stock Exchange. 1976. Requirements for Articles of Association. Johannesburg: JSE. 18p.

Wakoff, G. 1973. On Shareholders' Indifference to the Proceeds Price in Pre-emptive Rights Offerings. J. Fin. Quant. Anal., vol. 8, 835-836.

White, R.W. \& Lusztig, P.A. 1980. The Price Effects of Rights Offerings. J. Fin. Quant. Anal., vol. 15, 25-40.

Appendix A Companies included in the sample to investigate price movements of rights issues on the JSE

Anglo American Properties Ltd.

Anglovaal Ltd.

Anglovaal Industries Ltd.

Argus Printing and Publishing Co. Ltd.

Bank Holdings Corp. of S. Africa Ltd.

Boland Bank Bpk.

Boumat Ltd.

Centrecity Properties Ltd.

Consolidated Holdings Ltd.

Consumex Ltd.

Crown Food Holdings Ltd.

Dabi Mining Holdings Ltd.
Edgars Stores Ltd.

Eriksen Industrial Ltd.

Eureka Industrial Ltd.

Farg-Ag Ltd.

Federale Volksbeleggings Bpk.

Fralex Holdings Ltd.

Fraser Alexander Ltd.

Gant's Holdings Ltd.

General Mining Union Corp. Ltd.

Global Mining and Industrial Corp. Ltd.

Harwill Investments Ltd.

Hill Samuel Group (SA) Ltd.

Interboard Ltd.

Javcor Ltd.

Kanhym Investments Ltd.

Metair Investment Ltd.

Metro Corporation Ltd.

Nedbank Group Ltd.

Ned-Equity Insurance Co. Ltd.

Northam Platinum Ltd.

Ocean Manufacturing Group Ltd.

Pepgro Ltd.

Pepkor Ltd.

Pioneer Property Fund.

Punch Line Holdings Ltd.

Quinton Hazell Superite Holdings Ltd.

Redgwood Holdings Ltd.

Rex Truform Clothing Co. Ltd.

Russells Furniture L.td.

Saficon Investment Ltd.

Sage Holdings Ltd.

Sappi Ltd.

Standard Bank Investment Corp Ltd.

Springs Dagga Gold Mines Ltd.

Television and Electrical Holdings Ltd.

Trans Hex Group Ltd.

Transkei Sun International Ltd.

Union Steel Corp. of S.A. Ltd. 